\title{
Application of Green Environmentally Friendly Materials in Food Packaging
}

DOI: $10.15255 /$ KUI.2017.035 KUI-43/2017

Original scientific paper Received August 30, 2017 Accepted October 26, 2017

\section{J. X. $L i^{*}$}

This work is licensed under a Creative Commons Attribution 4.0

\author{
School of Art, Zhengzhou University of Science and Technology, Zhengzhou, Henan, P.R. China
}

\begin{abstract}
|| Abstract
With social development, requirements on the spiritual and material life have increased. However, some environmental issues appear, for example, in food packaging. Application of environment-friendly materials in food packaging has been more and more attractive. This study analyses the characteristics of degradable food packaging material and the existing problems, proposes the manufacturing of food packaging with poly(lactic acid)/ nanocrystalline cellulose composite material, tests its thermal and mechanical properties, and applies it to the design of food packaging. The results demonstrate that the thermal and mechanical properties of the material could satisfy the requirements of food packaging and that the material is applicable to the design of food packaging in the future. This work provides a reference for the application of green, environment-friendly materials in the design of food packaging.
\end{abstract}

\section{\| Keywords}

Green environment-friendly materials, poly(lactic acid)/nanocrystalline cellulose composite material, food packaging design

\section{Introduction}

Poly(lactic acid), a green material with favourable biocompatibility and degradability, has been applied in fields such as food packaging and medical devices production. ${ }^{1}$ However, the foam forming of poly(lactic acid) is difficult due to the defects of tender texture and poor thermostability. Hence, the improvement of the thermostability and hardness of poly(lactic acid) has been a concern of scholars in different countries. Q. Yuan ${ }^{2}$ developed a composite material by combining Ce ion doped hydroxyapatite with poly(lactic acid) and tested the representation. The results demonstrated that the composite had high thermostability. C. F. J. Kuo et al. ${ }^{3}$ added butylene succinate into poly(lactic acid) to improve the tenacity of the poly(lactic acid). The experiment demonstrated that the composite material that was made from butylene succinate and poly(lactic acid) had $27.49 \%$ reduction in bending strength, $13.47 \%$ improvement in tensile strength, and $22.95 \%$ improvement in impact strength. In this study, the correlation between packaging materials and packaging design was analysed. Nanocrystalline cellulose was added to poly(lactic acid) to improve the mechanical and degradation performance. Moreover, experiments were carried out to verify that the mechanical properties and thermostability had improved after the addition of nanocrystalline cellulose, and improved with the increase in the amount of nanocrystalline cellulose. The composite also had favourable degradability in soil. Therefore, it can be extensively applied in the food packaging field as a packaging material.

\section{Correlation between packaging material and packaging design}

\subsection{Aesthetic property of materials in packaging design}

The aesthetic attributes of materials in packaging design are mainly as follows:

(1) Natural property includes the vital signs and authenticity of materials and people's association to materials. ${ }^{4}$ The vital signs of materials refer to inherent colours and temperature, for example, wood and leather. ${ }^{5} \mathrm{Au}-$ thenticity refers to the natural beauty of materials. Association refers to the emotional colour that materials remind people of.

(2) Technological nature mainly includes the artistic polishing and structure manufacture of materials. ${ }^{6}$ Processing technology is different for different materials. The functions of packaging should be referred to during selection of packaging material. The technological nature of packaging will increase with the emergence of new materials.

(3) Social attribute includes ecological nature, functionality, and emotional interaction. ${ }^{7}$ Whether materials are green should be considered when packaging materials are selected. ${ }^{8}$ Functionality means the usability of materials as packaging material. Emotional interaction refers to the material and spiritual concern of materials for people. 


\subsection{Sustainability of packaging materials}

In packaging design, materials such as metal can be recycled. ${ }^{9}$ The reusability of packaging materials is the key to sustainability. ${ }^{10}$ Reasonable structural design can make the decomposing and recycling of packaging before being discarded. Currently, sustainable materials mainly include metal and plastic.

Using renewable materials is one of the important ways of protecting the environment. ${ }^{11}$ Renewable materials such as bamboo and wood have certain reusability. In packaging material design, the application of renewable materials can achieve unexpected effects. For example, waterproof and heat-resistant packaging materials can be made based on the physical properties of wood pulp during the manufacture of paper tableware.
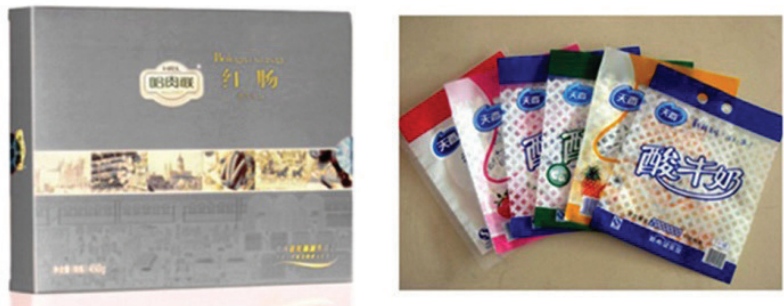

Fig. 1 - Green environment-friendly materials (left) and environmentally unfriendly materials (right)

Based on the characteristics of materials mentioned above, this study designed packaging with poly(lactic acid)/nanocrystalline cellulose composite material and tested the thermal property, mechanical property, and degradability of the materials. The results demonstrated that the material could be used as green packaging material.

\section{Material preparation and application}

Raw materials included poly(lactic acid) (Foshan Zhulian Plastic Co., Ltd., China), lab-synthesized nanocrystalline cellulose, dichloromethane (Langfang Pengcai Fine Chemicals Co., Ltd., China), disodium hydrogen phosphate (Langfang Pengcai Fine Chemicals Co., Ltd., China), monopotassium phosphate (Langfang Pengcai Fine Chemicals Co., Ltd., China) and sodium chloride (Langfang Pengcai Fine Chemicals Co., Ltd., China).

Experimental equipment included electronic scales (Henan Zhongliang Scientific Experimental Apparatus Co., Ltd., China), electric mixer (Shanghai SIEHE Mechanical \& Electrical Equipment Co., Ltd., China), electronic multi-purpose furnace (Henan Zhongliang Instrument Co., Ltd., China), electronic energy-saving temperature-controlled instrument (Henan Zhongliang Instrument Co., Ltd., China), differential scanning calorimeter (Henan Zhongliang Instrument Co., Ltd., China), tensile testing machine (Jinan Zhongluchang Testing Machine Co., Ltd., China) and electro-thermal vacuum drying oven (Nanjing Nuofan Machinery Co., Ltd., China).

The preparation of poly(lactic acid)/nanocrystalline cellulose composite was as follows. Firstly, $20 \mathrm{~g}$ of nanocrystalline cellulose was dried in vacuum environment $\left(60{ }^{\circ} \mathrm{C}\right)$ for $24 \mathrm{~h}$. Then a certain amount of nanocrystalline cellulose was added to a 3-mouth flask, which was loaded with $50 \mathrm{ml}$ of dichloromethane and dispersed with ultrasonic wave for $1 \mathrm{~h}$. One hour later, the mixture in the 3-mouth flask was processed by warm bath $\left(50{ }^{\circ} \mathrm{C}\right)$ and stirred at constant speed. Then, $20 \mathrm{~g}$ of poly(lactic acid) was added into the 3-mouth flask and stirred. After poly(lactic acid) had thoroughly dissolved, the solution was poured into a container, dried at normal temperature for $24 \mathrm{~h}$, and finally dried in a vacuum drying oven for $24 \mathrm{~h}$. Poly(lactic acid)/ nanocrystalline cellulose composite with $50 \%$ nanocrystalline cellulose was obtained. The composites with different ratio of poly(lactic acid) to nanocrystalline cellulose were obtained by adjusting the content of the two materials.

\section{Experiment}

\subsection{Thermodynamic analysis experiment}

The obtained composite was cut into strips of $2 \mathrm{~mm} \times 2 \mathrm{~mm} \times 10 \mathrm{~mm}$. Before testing, the sample was dried at $50{ }^{\circ} \mathrm{C}$ for $5 \mathrm{~h}$. Differential scanning calorimetry was then performed on the samples using a differential scanning calorimeter. Under the protection of argon, the room temperature rose to $500{ }^{\circ} \mathrm{C}$, and the heating rate was $20{ }^{\circ} \mathrm{Cmin}^{-1}$.

\subsection{Mechanical test}

The composite material was cut into dumbbell-shaped tensile strips. The total length of the strips was $150 \mathrm{~mm}$; the distance between fixtures was $115 \mathrm{~mm}$; the length and width of the parallel section in the middle were $60 \mathrm{~mm}$ and $15 \mathrm{~mm}$, respectively; the scale distance was 50 , the width of ends was $25 \mathrm{~mm}$, the thickness was $4 \mathrm{~mm}$; the radius was $60 \mathrm{~mm}$. The error of the tensile strips was $\pm 0.5 \mathrm{~mm}$.

The tensile strength, elongation at break, and elasticity modulus of the strips was then tested using a tensile testing machine according to GBT1040.5-2008 standards.

The computational formula of the tensile strength $\left(\sigma_{M}\right)$ was

$$
\sigma_{\mathrm{M}}=\frac{F}{a \cdot b}
$$

where $F$ is the maximum load, $a$ is the width of the test specimen, and $b$ is the thickness of the test specimen.

The computational formula of the elongation at break was

$$
\varepsilon=\Delta l / I_{0}
$$


where $\Delta /$ is the displacement value of the test specimen when broken, and $I_{0}$ is the original length of the test specimen.

The computational formula of elastic modulus $(E)$ was

$$
E=\sigma / \varepsilon
$$

where $\sigma$ is the stress of unit area of the test specimen, and $\varepsilon$ is the morphological change of the test specimen.

To ensure the accuracy of data, the test was repeated ten times, and the average value was calculated and taken as the final result.

\subsection{Degradability test}

The biological degradability of the sample was expressed by the quality loss of organism. The composite material was cut into $40 \mathrm{~mm} \times 40 \mathrm{~mm}$ and weighed. Then it was buried with yellow cinnamon soil with $\mathrm{pH}=6.9$, and the covering thickness of the yellow cinnamon soil was $60 \mathrm{~mm}$. After 5, 10, 20, 40, 60 and 90 days, the sample was taken out and washed with distilled water, followed by washing with ultrasonic wave for $2 \mathrm{~h}$. The sample was then dried in a vacuum drying oven $\left(60^{\circ} \mathrm{C}\right)$ for $12 \mathrm{~h}$ and weighed.

The computational formula of quality loss was:

$$
G=\frac{G_{1}-G_{2}}{G_{1}}
$$

where $G_{1}$ is the quality before degradation, and $G_{2}$ is the quality after degradation.

\section{Results}

\subsection{The thermoanalysis representation of the composite materials with different content of nanocrystalline cellulose}

The thermoanalysis of the composite material could be expressed by thermal weight loss. The experimental results are shown in Table 1.

It could be noted from Table 1 that the initial thermal decomposition temperature was $334.25{ }^{\circ} \mathrm{C}$ and the highest decomposition temperature was $363.85^{\circ} \mathrm{C}$. After the addition of nanocrystalline cellulose, the thermal decomposition temperature became lower and slowly decreased with the increase in nanocrystalline cellulose content. This is because nanocrystalline cellulose, which is an organic nanoparticle, has poor thermostability. When the content of nanocrystalline cellulose was $3 \%$, the composite had a favourable thermostability. Hence, it was concluded that the addition of nanocrystalline cellulose improved the thermal degradation velocity, and thermostability of the composite could satisfy the requirements.

\subsection{Mechanical representation of composite materials with different nanocrystalline cellulose content}

The tensile property of the composite materials with different nanocrystalline cellulose content is shown in Table 2.

It could be noted from Table 2 that the tensile property of the composite material increased firstly and then decreased with the increase in nanocrystalline cellulose content; when the content of nanocrystalline cellulose was $2 \%$, the tensile strength and elasticity modulus of the composite material was the greatest; the breakage elongation

Table 1 - Thermoanalysis representation of the composite materials with different content with nanocrystalline cellulose

\begin{tabular}{l|c|c|c|c}
\hline & $\begin{array}{c}\text { Pure (polyl actic) } \\
\text { acid }\end{array}$ & $\begin{array}{c}1 \% \text { nanocrystalline } \\
\text { cellulose }\end{array}$ & $\begin{array}{c}2 \% \text { nanocrystalline } \\
\text { cellulose }\end{array}$ & $\begin{array}{c}3 \% \text { nanocrystalline } \\
\text { cellulose }\end{array}$ \\
\hline $\begin{array}{l}\text { initial decomposition } \\
\text { temperature } /{ }^{\circ} \mathrm{C}\end{array}$ & 334.25 & 330.24 & 326.36 & 315.21 \\
$\begin{array}{l}\text { highest decomposition } \\
\text { temperature } /{ }^{\circ} \mathrm{C}\end{array}$ & 363.85 & 362.59 & 360.97 & 360.01 \\
\hline
\end{tabular}

Table 2 - Tensile property of the composite materials with different nanocrystalline cellulose content

\begin{tabular}{l|c|c|c|c}
\hline & $\begin{array}{c}\text { Pure (polyl actic) } \\
\text { acid }\end{array}$ & $\begin{array}{c}1 \% \text { nanocrystalline } \\
\text { cellulose }\end{array}$ & $\begin{array}{c}2 \% \text { nanocrystalline } \\
\text { cellulose }\end{array}$ & $\begin{array}{c}3 \% \text { nanocrystalline } \\
\text { cellulose }\end{array}$ \\
\hline tensile strength/MPa & 41.53 & 48.66 & 56.74 & 48.12 \\
breakage elongation /\% & 8.59 & 6.98 & 7.23 & 6.72 \\
elastic modulus $/ \mathrm{MPa}$ & 907.66 & 1358.33 & 1433.26 & 1355.69 \\
\hline
\end{tabular}


increased firstly and then decreased with the increase in nanocrystalline cellulose content.

\subsection{Degradability representation of the composite materials with different nanocrystalline cellulose content}

The degradation curve of the composite materials with different nanocrystalline cellulose content is shown in Fig. 2.

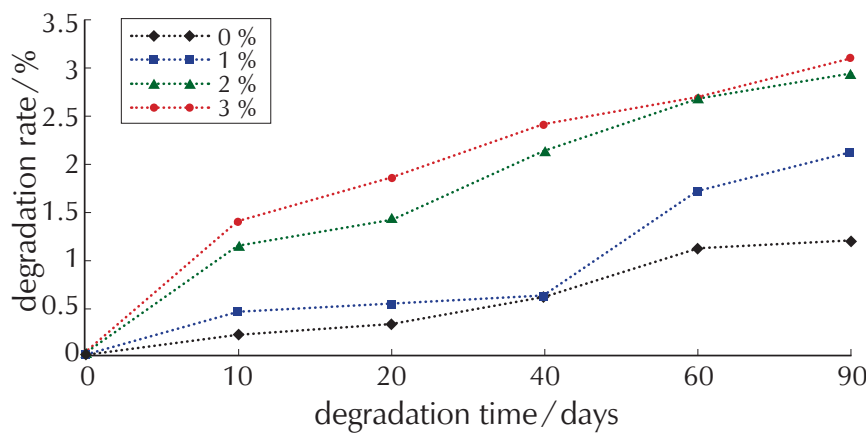

Fig. 2 - Degradability of the composite materials with different nanocrystalline cellulose content

It could be noted from Fig. 2 that the degradation speed was increasingly higher with the increase in nanocrystalline cellulose content; the degradation rate of the composite materials, which contained nanocrystalline cellulose was basically the same as that of the pure poly(lactic acid) material from day 1 to 16 . After day 16, the quality loss speed of the composite materials significantly improved. It could be concluded that nanofibre materials could affect the degradation rate of the composite materials, and the degradation rate increased with the increase in nanocrystalline cellulose content. Nanocrystalline cellulose has favourable hydrophilia; with the increase in nanocrystalline cellulose content, the hygroscopic property of the composite materials had improved significantly, leading to the hydrolysis of the composite materials in soil and then enzymatic degradation.

Poly(lactic acid) and nanocrystalline cellulose are biodegradable materials and the development and application of the two materials have multiple practical significance. Poly(lactic acid)/nanocrystalline cellulose composite has been extensively applied in fields such as food packaging design and industrial production for its favourable biodegradability and mechanical performance. More and more attention to the composite will be paid under the background of sustainable development. W. J. Zhen et al. ${ }^{12}$ prepared poly(lactic acid)/nanocrystalline cellulose composite material using solution casting method, applied it in the sports industry and found that the composite material had $31.42 \%$ improvement in hygroscopic property, $42.33 \%$ improvement in degradability and improved mechanical property. F. Lu et al. ${ }^{13}$ found that adding nanocrystalline cellulose into poly(lactic acid) could enhance crystallization rate by $38.48 \%$. Peony cake as a special food sells well, but the packaging of peony cake consumes many materials, which results in material waste and environmental pollution. The composite material developed in this study has favourable degradability, thermal and mechanical properties, which can avoid the deformation of peony cake caused by improper operation during transportation. Moreover, the composite material is easy to shape. Hence, the material can be painted with peony to represent the special characteristics of central plan culture.

\section{Conclusion}

This study prepared poly(lactic acid)/nanocrystalline cellulose composite material and found that the addition of nanocrystalline cellulose could improve thermostability, degradability, and mechanical characteristics. The application of the composite in food packaging is beneficial to the design of packaging. Moreover, it can protect food in the packaging due to its favourable thermostability and mechanical performance. Because of its good degradability, food packaging can be easily degraded by soil, which satisfies the aim of sustainable development. Hence, the composite has a broad prospect in the design of food packaging.

\section{List of abbreviations and symbols}

a - width of test specimen

b - thickness of test specimen

$F \quad$ - maximum load

$G_{1}$ - quality before degradation

$G_{2}$ - quality after degradation

$\Delta l$ - displacement value of test specimen

$I_{0} \quad$ - original length of test specimen

$\sigma \quad$ - stress of unit area of test specimen

$\sigma_{\mathrm{M}}$ - tensile strength

$\varepsilon \quad-$ morphological change of test specimen

\section{References}

\section{Literatura}

1. C. P. Radano, G. L. Baker, M. R. Smith III, Stereoselective Polymerization of a Racemic Monomer with a Racemic Catalyst: Direct Preparation of the Polylactic Acid Stereocomplex from Racemic Lactide, J. Am. Chem. Soc. 122 (7) (2000) 1552-1553, doi: https://doi.org/10.1021/ ja9930519.

2. Q. Yuan, C. Qin, J. B. Wu, A. P. Xu, Z. Q. Zhang, J. Q. Liao, S. X. Lin, X. Z. Ren, P. X. Zhang, Synthesis and characterization of Cerium-doped hydroxyapatite/polylactic acid composite coatings on metal substrates, Mater. Chem. Phys. 182 (2016) 365-371, doi: https://doi.org/10.1016/j. matchemphys.2016.07.044.

3. C. F. J. Kuo, W. L. Lan, C. Y. Chen, H. C. Tasi, Property modification and process parameter optimization design of polylactic acid composite materials. Part I: polylactic acid toughening and photo-degradation modification and 
optimized parameter design, Text. Res. J. 85 (1) (2015) 13-25, doi: https://doi.org/10.1177/0040517514540766.

4. V. M. Paradiso, F. Caponio, C. Summo, T. Gomes, Influence of some packaging materials and of natural tocopherols on the sensory properties of breakfast cereals, Food Sci. Technol. Int. 20 (3) (2014) 161, doi: https://doi. org/10.1177/1082013213476074.

5. D. Labbe, N. Pineau, N. Martin, Food expected naturalness: Impact of visual, tactile and auditory packaging material properties and role of perceptual interactions, Food Qual. Prefer. 27 (2) (2013) 170-178, doi: https:// doi.org/10.1016/j.foodqual.2012.06.009.

6. C. Bastioli, Global Status of the Production of Biobased Packaging Materials, Starch - Stärke 53 (8) (2015) 351-355, doi: https://doi.org/10.1002/1521379X(200108)53:8<351::AID-STAR351>3.0.CO;2-R.

7. F. Li, K. Guan, P. Liu, G. Li, J. Li, Ingredient of Biomass Packaging Material and Compare Study on Cushion Properties, Int. J. Polym. Sci. 2014 (1) (2015) 1-7, doi: https:// doi.org/10.1155/2014/146509.

8. M. J. Sun, Natural Packaging Materials and Green Package Design, Adv. Mater. Res. 580 (2012) 497-500, doi: https:// doi.org/ 10.4028/www.scientific.net/AMR.580.497.

9. S. S. K. N. Jayanty, W. J. Sawaya, M. D. Johnson, Sustainable Distribution Design: Contrasting Disposable, Recyclable, and Reusable Strategies for Packaging Materials
Using a Total Cost Analysis with an Illustration of Milk Distribution. ASME 2010 International Design Engineering Technical Conferences and Computers and Information in Engineering Conference, Am. Soc. Mech. Eng. (2010) 417-425, doi: https://doi.org/10.1115/DETC2010-28823.

10. M. Drechsel, M. Bornschlegl, A. Dornhofer, S. Spreng, A model to assess the sustainability of manufacturing equipment using the example of a reusable frequency converter housing, Electric Drives Production Conference, IEEE (2014) 1-6, doi: https://doi.org/10.1109/ EDPC.2014.6984379.

11. G. Mensitieri, E. D. Maio, G. G. Buonocore, I. Nedi, M. Oliviero, L. Sansone, S. lannace, Processing and shelf life issues of selected food packaging materials and structures from renewable resources. Trend. Food Sci. Tech. 22 (2-3) (2011) 72-80, doi: https://doi.org/10.1016/j. tifs.2010.10.001.

12. W. J. Zhen, Z. Shan, The Preparation of Nano cellulose whiskers/polylactic acid composites, International Conference on Future Computer Science and Education, IEEE (2011) 123-125, doi: https://doi.org/10.1109/ ICFCSE.2011.38.

13. F. Lu, H. Yu, C. Yan, J. Yao, Polylactic acid nanocomposite films with spherical nanocelluloses as efficient nucleation agents: effects on crystallization, mechanical and thermal properties, RSC Adv. 6 (51) (2016) 46008-46018, doi: https://doi.org/10.1039/C6RA02768G.

\title{
SAŽETAK
}

\section{Primjena zelenih, ekološki prihvatljivih materijala u pakiranju hrane \\ Jixia $L i$}

\begin{abstract}
S razvojem društva povećali su se zahtjevi za kvalitetnijim duhovnim i materijalnim životom. Međutim, neki problemi u vezi sa zaštitom okoliša pojavljuju se, na primjer, pri pakiranju namirnica. U posljednje vrijeme za ambalažu sve se više upotrebljavaju ekološki prihvatljivi materijali. Ova studija analizira karakteristike i postojeće probleme s razgradljivim ambalažnim materijalima, predlaže proizvodnju ambalaže od kompozita poli(mliječne kiseline) i nanokristalne celuloze, provjerava toplinska i mehanička svojstva i primjenjuje ga na dizajn ambalaže. Rezultati pokazuju da toplinska i mehanička svojstva materijala zadovoljavaju zahtjeve ambalaže za hranu. Rad daje referenciju za primjenu zelenih, ekološki prihvatljivih materijala u dizajnu ambalaže za hranu.
\end{abstract}

\section{Ključne riječi \\ Zeleni, ekološki prihvatljivi materijali, kompozit poli(mliječne kiseline) i nanokristalne celuloze, izrada ambalaže za hranu}

School of Art, Zhengzhou University of Science and Technology, Zhengzhou, Henan, Kina
Izvorni znanstveni rad Prispjelo 30. kolovoza 2017. Prihvaćeno 26. listopada 2017. 